\title{
Amazônia indígena: a floresta como sujeito ${ }^{1}$ Indigenous Amazonia: the forest as a subject
}

\author{
Patrick Pardini (1) \\ Universidade Federal do Pará. Museu da UFPA. Belém, Pará, Brasil
}

Resumo: Cultivada, manejada pelos humanos durante milênios, a floresta amazônica alterou-se, tornou-se 'outra', sem deixar de ser floresta; manteve a sua autonomia de sujeito - sujeito da sua própria renovação e reprodução. Em outras palavras, a Amazônia tornou-se 'antropogênica' - a um só tempo cultural e natural, fruto de uma relação de mão dupla entre sujeitos: o Homem e a Floresta, na qual a ação de um não anula a do outro. Graças à Antropologia, sabemos que as sociedades indígenas da Amazônia conferem dignidade de pessoa ou sujeito aos não humanos. A relação entre sujeitos (simétrica, de troca e reciprocidade) é uma relação ética e também poética. Por outro lado, o que prevalece na civilização ocidental é a relação sujeito-objeto (assimétrica, autoritária, de poder e dominação), da qual se origina a Natureza-objeto, em oposição ao Homem-sujeito, único detentor de Cultura. Ora, 'o outro como objeto' é a negação do outro e a negação da ética. Nisso reside a alteridade radical dos modos de ser e pensar indígenas com relação ao Ocidente. Essa 'alteridade indígena' tem, para nós, valor de tesouro e sabedoria. Há, porém, um Ocidente criança e poeta que se reconhece nos povos indígenas e na sua experiência de mundo.

Palavras-chave: Sujeitos não humanos. Relação ética e poética. Alteridade indígena. Amazônia antropogênica. Sabedoria amazônica.

Abstract: Managed and cultivated by humans for millennia, the Amazon rainforest was altered, but (as the subject of its own renovation) is still a forest. In other words, Amazonia became 'anthropogenic' - both cultural and natural, the result of a two-way relationship between subjects: Man and the Forest, with the activities of one not nullifying those of the other. Thanks to anthropology, we know that the indigenous societies of Amazonia confer the dignity of a person or subject on non-humans. The relationship between subjects (symmetrical, dialogic, reciprocal) is an ethical as well as poetical relationship. On the other hand, what prevails in western civilization is the subject-object relationship (asymmetrical, authoritarian, dominating), which generates Nature as an object, opposed to Man as a subject, the sole bearer of Culture. Meanwhile, "the other as an object" means denying the other and denying ethics. This is the substance of the radical alterity of indigenous ways of being and thinking with regard to the West; this "indigenous alterity" for us is a treasure of wisdom. Yet there is a childlike, poetic West that recognizes itself in the indigenous people and in their experience of the world.

Keywords: Non-human subjects. Ethical and poetical relationship. Indigenous alterity. Anthropogenic Amazonia. Amazonian wisdom.

1 Este texto retoma, com novo enfoque, alguns conteúdos de artigo anteriormente publicado (Pardini, 2012).

Pardini, P. (2020). Amazônia indígena: a floresta como sujeito. Boletim do Museu Paraense Emílio Goeldi. Ciências Humanas, $15(1)$, e20190009. doi: 10.1590/2178-2547-BGOELDI-2019-0009

Autor para correspondência: Patrick Pardini. Universidade Federal do Pará. Museu da UFPA. Av. Gov. José Malcher, 1192, Nazaré. Belém, PA, Brasil. CEP 66055-260 (pardini@ufpa.br).

Recebido em 19/02/2019

Aprovado em 23/08/2019 
Se nos predispusermos à recepção não preconceituosa da psique indígena, e de tudo o que ela representa neste momento de crise dos valores ditos modernos, estaremos trabalhando para introduzir em nossa consciência de hoje a 'alteridade radical', uma lógica que nos

é desconhecida, uma estética nova, uma espiritualidade que não conhecemos, uma percepção, uma sensibilidade, um modo de

ser que ignoramos. Esta é a grande tarefa utópica para o século XXI brasileiro.

(Gambini, 2000, p. 26).

No decorrer dos últimos 35 anos, aproximadamente, a Ciência fez uma série de descobertas fundamentais relativas à Amazônia, no campo da Antropologia e da Arqueologia. Surgiram novos objetos teóricos, como as 'matas culturais' e os 'solos antropogênicos', que soterraram de vez o mito da floresta virgem. Avançou-se consideravelmente na compreensão das ecologias praticadas pelas sociedades indígenas contemporâneas, das suas filosofias e cosmologias. O 'tempo arqueológico' de longa duração veio completar este quadro, introduzindo nele a profundidade e a grandiosidade da dimensão temporal. O que importa, hoje, não é a extensão e a excelência do nosso saber sobre o outro, mas a revelação de um saber radicalmente outro e o reconhecimento, pela sociedade brasileira, dessa 'alteridade indígena', do seu valor.

\section{AMAZÔNIA ANTROPOGÊNICA: A FLORESTA- JARDIM, A FLORESTA-SUJEITO}

O que houve na Amazônia, durante toda a sua longa história pré-colonial, não foi a clássica antropização dos espaços naturais, a Cultura suplantando a Natureza de modo violento e irreversível, com base na pura e simples 'negação da floresta' (Quadro 1). O que houve foi o aparecimento, a invenção de uma autêntica 'cultura da floresta'2, isto é, a transformação cultural da floresta, o seu 'cultivo', sem que ela deixasse de ser floresta. Isso aconteceu porque, nas sociedades indígenas da planície amazônica, prevalece, não a relação sujeito-objeto, antropocêntrica, de poder e dominação ${ }^{3}$, mas a relação entre sujeitos, humanos e não humanos, baseada na troca e na reciprocidade.

De fato, sabe-se que essas sociedades conferem aos animais e às plantas, via de regra, os caracteres subjetivos da pessoa humana: consciência de si, motivações, afetos, capacidade comunicativa e sociabilidade e, com eles, estabelecem relações de pessoa para pessoa. Nas cosmologias ameríndias, observa o antropólogo Eduardo Viveiros de Castro:

... os humanos não têm o monopólio da posição de agente e sujeito; o mundo é habitado por diferentes espécies de sujeitos ou pessoas, humanas e não humanas, que o apreendem segundo pontos de vista distintos. . . . As relações entre uma sociedade indígena e os componentes de seu ambiente são pensadas e vividas como relações sociais, isto é, relações entre pessoas, ou ainda, como uma comunicação entre sujeitos que se interconstituem no ato e pelo ato da troca - troca que pode ser violenta e mortal, mas que não pode deixar de ser social. (Viveiros de Castro, 2005, pp. 123, 126-127).

Mesmo sendo cultivada e manejada pelos indígenas há mais de dez mil anos, a floresta amazônica mantém a sua autonomia de sujeito - sujeito da sua própria renovação e reprodução. Sendo sujeito (termo de uma relação ética), é

2 Tomo por empréstimo a expressão do sociólogo e jornalista Lúcio Flávio Pinto, que a utiliza num sentido propositivo e prospectivo: a cultura da floresta, na Amazônia, como 'projeto' ou 'utopia' - contra a incultura do desmatamento e como a "última possibilidade de civilização florestal na história do gênero humano" (Pinto, 2006a, 2006b, pp. 6-7). "Cultura da floresta" corresponde aqui às "Culturas Tropical e Antropical" demarcadas pelo arqueólogo Marcos Magalhães (2018, pp. 23-26).

3 É essa relação sujeito-objeto, fundamento da Representação, matriz da Natureza e do Antropocentrismo ocidentais, ancorada exemplarmente no pensamento cartesiano, na invenção da perspectiva linear e na Conquista das Américas, que está na origem da Ciência, da Técnica e da Estética ocidentais modernas (cf. Heidegger, 1958, 1962, 1968). "O ente só pode ser experimentado como objeto no momento em que o homem se torna sujeito", diz Heidegger (1968, p. 495), e os Tempos Modernos são a época em que "o homem torna-se sujeito para seus objetos" (Heidegger, 1968, p. 266). Por outro lado, "para os gregos, o homem não é absolutamente um sujeito: por isso, o ente não humano jamais pode ter o caráter de objeto" (Heidegger, 1968, p. 495). Existe, porém, o 'sujeito sem objetos', que é o sujeito ético e poético.

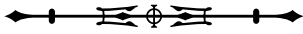


ela quem ensina aos humanos as boas práticas ecológicas, batizadas hoje de 'sustentáveis'.

As práticas ecológicas indígenas fazem aumentar, ao invés de reduzir, a biodiversidade florestal; elas tendem a modificar sutilmente os ecossistemas amazônicos, gerando ecologias induzidas e localizadas, ilhas de recursos cuja diversidade biológica é manejada e modelada em benefício das gerações presentes e futuras. $O$ destino a longo prazo de uma plantação aparentemente abandonada é tornar-se 'outra'. Os vestígios mais evidentes de cultivo humano se extinguiram, e o que resta hoje é uma porção de floresta mais rica e biodiversa, caracterizada pela alta frequência de espécies florestais úteis aos humanos (como a pupunheira, o pequiá, a bacaba, a copaíba), sinais remanescentes de antigo cultivo ou manejo florestal, ou seja, indicadores de uma 'mata cultural'4. Os castanhais da região de Marabá, no Pará, por exemplo, são considerados hoje uma mata cultural, ou 'floresta antropogênica'.

O arqueólogo Marcos Magalhães propôs recentemente a ideia de uma "Amazônia antropogênica", isto é, de uma Amazônia que é, a um só tempo e indissociavelmente, Cultura e Natureza. 'Antropogênico', aqui, deixa de ser simplesmente sinônimo de 'cultural' (gerado pelo homem) para designar o natural que foi alterado pelo cultural, tornou-se outro, sem deixar de ser 'natural' - sutil metamorfose essa (a antropogênese, o 'devir antropogênico') que se dá necessariamente na longuíssima duração, ou seja, numa escala de tempo 'arqueológica':

Considerar a floresta amazônica, ou parte dela, como sendo de origem antropogênica nos faz pensar que em algum tempo muito recuado e segundo modos práticos diversos, ela teve uma antropogênese para que hoje muitas de suas espécies sejam consideradas resultado da seleção cultural, mesmo em matas primárias autônomas.
... A ideia de que só florestas naturais primárias se desenvolvem em ambientes sem influência humana não se sustenta, pois haveria florestas de origem cultural que também se desenvolvem como florestas primárias. Por serem antropogenicamente consolidadas, as ações antrópicas teriam surgido em períodos muito recuados e hoje essas florestas se sustentariam e multiplicar-se-iam naturalmente, sem a necessidade da intervenção do ser humano. ... . [Na Amazônia], temos ambientes que ao longo de muitos séculos passaram por tantas interferências antrópicas que as espécies que neles predominam e florescem naturalmente são aquelas selecionadas culturalmente e não as nativas que um dia lá existiram. Isto é, são [ambientes] naturais porque, apesar de serem florestas antrópicas, compostas por espécies culturalmente selecionadas, as espécies dominantes não precisam mais do Homem, pois são autônomas, por se terem tornado antropogênicas. (Magalhães, 2016, pp. 11, 386).

A Amazônia não foi simplesmente 'antropizada', numa relação unidirecional entre sujeito e objeto, agente e paciente. Ela tornou-se 'outra': antropogênica. Ali, diz Magalhães (2016, p. 386), "os ambientes antropizados [culturais, cultivados] tornaram-se antropogênicos [naturais, autônomos]", numa relação de mão dupla, recíproca e reversível, entre dois agentes ou sujeitos: o Homem e a Floresta, na qual "a ação de um não anula a do outro" (Magalhães, 2016, p. 43). A Florestasujeito alterou-se, tornou-se outra, sem deixar de ser floresta. Ela incorporou e assumiu como 'sua' a seleção cultural das espécies, a tal ponto que os ambientes onde isso aconteceu podem ser considerados, hoje, 'mata primária'!

De acordo com a experiência ameríndia, é da natureza do ser, em qualquer uma das suas manifestações, diferir de si mesmo, tornando-se outro. Cada ser é não só o que é, mas também, virtualmente, o que não é. A diferença (intensiva, de afetos) é interna ao ser, e a alteridade é constitutiva da identidade. Cada denominação (humanos, animais, plantas, espíritos etc.)

\footnotetext{
4 "Matas culturais" - conceito introduzido em 1989 pelo antropólogo William Balée, e que contribuiu para a emergência da Ecologia Histórica - são trechos da floresta amazônica que apresentam sinais de ocupação humana num passado remoto. Não são vestígios arqueológicos no sentido clássico, são sinais vivos, de natureza vegetal, que a própria floresta incorporou na sua composição e fisionomia, mas que não são imediatamente visíveis. A existência de matas culturais assinala práticas ancestrais de manejo florestal indígena e um processo imemorial de 'humanização' da floresta amazônica. (cf. Balée, 1989).
} 
designa menos uma classe ou gênero de seres do que um tipo de experiência, uma qualidade, um modo de ser ou um ponto de vista, sempre passível de reversão ${ }^{5}$. Por isso, diríamos que o ser ameríndio é menos um 'ser', uma essência, do que um 'vir-a-ser', um 'tornar-se-outro'.

No mundo ocidental, regido pelo pensamento lógico e pelo princípio de não contradição, as diferenças são externas e extensivas, e servem para repartir os indivíduos em uma série de essências ou identidades fixas (classe, gênero ou espécie). "Cada ser é só o que é, e só o é por não ser o que não é" (Viveiros de Castro, 2006, p. 324). Floresta é floresta, plantação é plantação!

A Amazônia subverte essa ideia, duplamente. Se, para arqueólogos e antropólogos, boa parte da floresta amazônica, de natureza antropogênica, foi, por assim dizer, 'plantada' ao longo dos séculos pelos humanos ${ }^{6}$ (sem esquecer a ação dos animais dispersadores de sementes: pássaros, macacos, roedores, morcegos etc.), para os indígenas, a floresta é uma imensa plantação não humana - "sobre-humana", segundo o antropólogo Philippe Descola, sendo cultivada pelos espíritos protetores (Descola, 1986, p. 398). Para os Achuar, povo da Amazônia equatoriana, a floresta é cultivada por Shakaim, espírito tutelar das plantas, mestre dos destinos vegetais e "grande jardineiro da floresta" (Descola, 1986, p. 271). Entre os Jodï da Venezuela, no dizer dos antropólogos Stanford e Egleé Zent, "many so-called 'wild' plants are considered to be the cultivated crop of spiritual or mythical figures, which in turn are viewed as the farmers of the forest" (S. Zent \& E. Zent, 2012, p. 303). Na perspectiva dos Yanomami, as árvores da floresta e as plantas cultivadas não crescem sozinhas, mas por obra de Në roperi, o espírito da fertilidade, que faz crescer a vegetação por onde passa e se parece com um ser humano, mas é visível apenas para os xamãs:
É ele que faz acontecer a riqueza da floresta e que, desse modo, alimenta os humanos e a caça. É ele que faz sair da terra todas as plantas e frutos que comemos. Seu nome é o de tudo o que prospera, tanto nas roças como na floresta. ... Assim que o xamã faz dançar Në roperi, as flores começam a desabrochar nas árvores. Em seguida, os galhos ficam férteis e carregados de frutas. (Kopenawa \& Albert, 2015, pp. 207, 209).

Para os Yanomami, a floresta é inseparável da terra que a suporta, chamada por eles de 'pele da floresta'. Urihi a, a 'terra-floresta', é uma entidade viva, animada, segundo o antropólogo Bruce Albert, por "uma complexa dinâmica de trocas, de conflitos e de transformações entre as diferentes categorias de existentes que a povoam, sujeitos humanos e não humanos, visíveis e invisíveis" (Albert \& Kopenawa, 2003, p. 46).

Assim fala o xamã yanomami Davi Kopenawa:

que os brancos chamam natureza, em nossa língua, é urihi a, a terra-floresta. . . . A floresta está viva, é daí que vem sua beleza. É ela que nos anima. Está bem viva. Os brancos talvez não ouçam seus lamentos, mas ela sente dor, como os humanos. Suas grandes árvores gemem quando caem e ela chora de sofrimento quando é queimada. . . . A floresta tem um sopro de vida muito longo. É a sua respiração. $\bigcirc$ sopro dos humanos, ao contrário, é muito breve. Vivemos pouco tempo e morremos depressa. Já a floresta, se não for destruída sem razão, não morre nunca. Não é como o corpo dos humanos. Ela não apodrece para depois desaparecer. Sempre se renova. É graças à sua respiração que as plantas que nos alimentam podem crescer. A floresta tem coração e respira, mas os brancos não percebem. Não acham que ela esteja viva. . . . É nossa floresta que cria desde sempre os animais e peixes que comemos. Ela alimenta seus filhotes e os faz crescer com os frutos de suas árvores. (Kopenawa \& Albert, 2015, pp. 468-479).

A esta Floresta-sujeito, sensível e inteligente, termo de uma relação profundamente ética e poética, contrapõe-se a visão ocidental da floresta como natureza, meio ambiente ou paisagem, isto é, 'objeto' do nosso olhar estético-cultural, das nossas representações artísticas, do nosso conhecimento

\footnotetext{
5 Acompanho aqui as análises de Viveiros de Castro (2006), em "A floresta de cristal: notas sobre a ontologia dos espíritos amazônicos". Ser A e não A ao mesmo tempo faz do pensamento ameríndio um pensamento metafórico, ou seja, poético, como veremos adiante.

6 ". . . se pode afirmar que, no mínimo, no mínimo, no mínimo mesmo, 60\% do total das terras não alagáveis disponíveis na Amazônia já eram antropogênicas [3.500 anos atrás]" (Magalhães, 2016, p. 315).
}

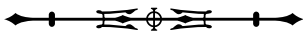


científico e das nossas leis de proteção. A 'paisagem' depende do nosso olhar, enquanto a 'mãe-terra' ou 'terra-floresta' é o que sustenta a existência humana.

\section{A RADICAL ALTERIDADE INDÍGENA COM RELAÇÃO AO OCIDENTE (ADULTO, MASCULINO E PROSAICO)}

Os ameríndios surgem historicamente, e de forma exemplar, como 'o outro do Ocidente', ou seja, como 'objeto do Ocidente-sujeito' - pois esta é a fórmula do antropocentrismo ocidental: o 'eu' como sujeito e o outro como objeto. O sujeito antropocêntrico (o Ocidente, sujeito da Conquista) precisa do outro como objeto para se afirmar como sujeito, 'eu' soberano.

O filósofo e historiador Tzvetan Todorov, estudioso da Conquista da América sob o ângulo da "questão do outro", analisa: "a descoberta do outro tem vários graus, desde o outro como objeto, confundido com o mundo que o cerca, até o outro como sujeito, igual ao $\underline{\mathrm{eu}}$, mas diferente dele" (Todorov, 2011, p. 360).

"O outro como sujeito: igual ao eu, mas diferente dele" expressa a plena aceitação do outro, ou seja, o "reconhecimento ético" (Leopoldo \& Silva, 2017, p. 95) enquanto reconhecimento e aceitação da "Igualdade com Diferença'. Mas o que Todorov descobriu, ao investigar a percepção que Cristóvão Colombo e os demais europeus tinham dos ameríndios, foram outras duas figuras da alteridade, figuras corrompidas, 'degradadas':

1) a Igualdade sem Diferença, quando a percepção da Igualdade (o índio é um ser completamente humano, igual a mim, pois somos todos iguais perante Deus) se degrada em Identidade: o outro idêntico a mim, assimilado (índios catequizados e batizados);

2) a Diferença sem Igualdade, quando a percepção da Diferença se degrada em Hierarquia: o outro inferior a mim, subjugado (índios escravizados).

Segundo Todorov (2011, p. 64), a contradição entre as duas proposições - entre "o assimilacionismo, que implica uma igualdade de princípio", e "a ideologia escravagista, que pressupõe a inferioridade dos índios" - se resolve, na mente de Colombo, numa alternativa grosseira: os índios "que ainda não são cristãos só podem ser escravos: não há uma terceira possibilidade".

Sobre Colombo, diz ainda Todorov (2011, pp. 58, 66, 68-69):

\begin{abstract}
Colombo recusa a existência de uma substância humana realmente outra, que possa não ser meramente um estado imperfeito de si mesmo. ... Mesmo quando não se trata de escravidão, o comportamento de Colombo implica o não reconhecimento do direito dos índios à vontade própria; implica que os considera, em suma, como objetos vivos. . . . Como Colombo pode estar associado a estes dois mitos aparentemente contraditórios, um em que o outro é um "bom selvagem", e o outro em que é um "cão imundo", escravo em potencial? É porque ambos têm uma base comum, que é o desconhecimento dos índios, a recusa em admitir que sejam sujeitos com os mesmos direitos que ele, mas diferentes. Colombo descobriu a América, mas não os americanos. Toda a história da descoberta da América, primeiro episódio da Conquista, é marcada por esta ambiguidade: a alteridade humana é simultaneamente revelada e recusada.
\end{abstract}

Ademais, Todorov (2011, pp. 95-96) aponta uma diferença fundamental entre ameríndios e europeus na sua relação com o mundo:

\begin{abstract}
Há duas grandes formas de comunicação, uma entre os homens, e outra entre os homens e o mundo; . . . os índios cultivam principalmente esta última, ao passo que os espanhóis cultivam principalmente a primeira. Estamos habituados a conceber somente a comunicação interhumana, pois, o "mundo" não sendo um sujeito, o diálogo com ele é bastante assimétrico (se é que há diálogo).
\end{abstract}

O mundo não sendo um sujeito, os europeus não dialogam com ele - à diferença dos índios, diz Todorov (2011). De fato, as culturas ameríndias oferecem um modo de ser e pensar próprio, radicalmente 'outro' com relação ao Ocidente, porque não se baseia na relação sujeito-objeto, antropocêntrica, mas na relação sujeitosujeito, cosmocêntrica - estendida ao mundo, aos não humanos. A relação entre sujeitos (simétrica, dialógica, de troca e reciprocidade) é uma relação ética e também poética. Ao promover uma sociabilidade generalizada 
entre sujeitos humanos e não humanos, ela estabelece o domínio universal da Cultura - no universo indígena, não há Natureza, tudo é Cultura?

Por outro lado, o que prevalece na civilização ocidental é a relação sujeito-objeto (assimétrica, autoritária, arrogante, de poder e dominação), da qual se origina a Natureza-objeto, em oposição ao Homem-sujeito, único detentor de Cultura. Ora, 'o outro como objeto' é a negação do outro e a negação da ética.

Há, porém, um Ocidente minoritário, criança e poeta, que se reconhece nos povos indígenas - na sua experiência ética e poética, na sua capacidade de dialogar com o mundo, na sua adesão ao invisível e ao sagrado.

Apresentamos no Quadro 1 uma proposta dos principais indicadores da alteridade indígena (exceto os da esfera política).

O Ocidente não é monolítico, claro, tem suas brechas e fraturas. Em alguns momentos, é capaz de se aproximar dos modos de ser, perceber e pensar ameríndios, não tanto pela via da Ciência, mas pela via da Arte enquanto Poesia, experiência poética. Isto porque pensar, perceber e expressar o mundo como sujeito é uma experiência (ética, além de poética) universal, compartilhada pelos povos indígenas com as crianças e os artistas e poetas, não só do Ocidente, mas de todos os quadrantes e de todas as épocas ${ }^{8}$. Por isso, o Ocidente criança e poeta, 'parente' dos ameríndios, está virtualmente situado na coluna esquerda do Quadro 1, em oposição ao Ocidente adulto e prosaico, situado à direita.

O que a Ciência ocidental tem conseguido ultimamente, é:

- fazer sua revolução epistemológica e cumprir seu papel ético no campo da Antropologia, ciência do outro, quando o outro deixa de ser objeto para ser sujeito do conhecimento', e todas as vezes que um(a) antropólogo(a) cumpre para valer o seu próprio rito de passagem: a iniciação ao outro, à radical alteridade do outro, sendo ensinado(a) pelo outro; há exemplos extraordinários disso (cf. Pozzobon, 2002);

- colocar-se como aliada política (e afetiva) dos povos indígenas ${ }^{10}$;

- $\quad$ reconhecer subjetividades não humanas no campo da Biologia, traduzindo-as em termos científicos: inteligência animal, inteligência vegetal/florestal11";

- ' 'personalizar' a Natureza no campo do Direito, considerando-a como 'sujeito de direito'"12;

- $\quad$ ser uma boa intérprete das filosofias, cosmologias e ecologias indígenas.

7 Cultura-Natureza e sujeito-objeto - estes dois pares de categorias antagônicas do pensamento ocidental - estão vinculados, sendo a Natureza 'objeto' e a Cultura 'atributo de sujeitos': é partindo deste pressuposto e dos entendimentos trazidos pela Antropologia que nos é possível afirmar, com referência à cosmovisão ameríndia, a ausência da ideia de Natureza e o domínio universal da Cultura, isto é, o domínio dos sujeitos, humanos e não humanos. Por outro lado, definimos a Amazônia antropogênica como entrelaçamento de Natureza e Cultura, floresta e jardim. São duas proposições distintas, que não se contradizem, pois pertencem a duas lógicas diferentes - uma cosmológica, a outra ecológica -, sendo cada uma válida dentro da sua esfera própria de pensamento, com acepções próprias e distintas de Cultura e Natureza.

8 Sem falar daquelas formas de vida arquetípicas e universais, como as do jardineiro, do pastor, do caçador e do pescador, propensas a relações de 'pessoa para pessoa' entre humanos e não humanos (plantas, animais), de tal modo que se pode falar, neste caso, em ética do jardineiro, ética do pastor, ética do caçador, ética do pescador etc. Esta última, perfeitamente ilustrada por um romance como "O velho e o mar", de Ernest Hemingway (1962).

9 Belo exemplo disso foi a publicação do livro "A queda do céu", de 2015, obra de Antropologia na qual prevalecem a fala e a autoria/ autoridade do xamã yanomami Davi Kopenawa, tendo o antropólogo Bruce Albert por coadjuvante.

10 Cf., por exemplo, as "Declarações de Belém", do I Congresso (1988) e do XVI Congresso Internacional de Etnobiologia (2018) ("Declaração de Belém", 1988, 2018).

11 A exemplo do neurobiologista Stefano Mancuso, criador do conceito de "neurobiologia vegetal" e autor de "A inteligência das plantas" (Mancuso \& Viola, 2018).

12 O rio Whanganui, por exemplo, venerado pelos Maori da Nova Zelândia, foi reconhecido como 'personalidade jurídica' em 2017. A Constituição do Equador - país amazônico - foi pioneira em 2008 ao elevar a Pacha Mama (Mãe-Terra) a titular de direitos, superando o antropocentrismo e fazendo opção pelo 'ecocentrismo', segundo os comentaristas. E mais especificamente, desde meados do século passado, há um debate em curso sobre "Direitos Animais" e "Ética Animal".

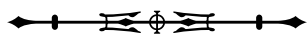


Quadro 1. Indicadores da alteridade indígena, ou seja, da alteridade radical dos modos de ser e pensar das culturas ameríndias da floresta tropical - distintas das "Altas Culturas andinas", de acordo com a conceituação do antropólogo Pierre Clastres (2003, p. 98) - com relação ao ocidente enquanto civilização, nas esferas cosmológica, ética, psicológica, epistemológica e ecológica. Fontes: Descola (2005), Gambini (2000), Heidegger (1958, 1962, 1968), Magalhães (2016), Pinto (2006a), Rimbaud (1984), Tible (2013), Tiburi (2016), Todorov (2011), Viveiros de Castro (2005, 2006). * no sentido geográfico das 'áreas antropizadas' (rodovias, ferrovias, pastos, plantações, zonas urbanas), onde antes havia floresta.

\begin{tabular}{|c|c|}
\hline CULTURAS AMERÍNDIAS & OCIDENTE \\
\hline \multicolumn{2}{|c|}{ Relação entre mim e o outro (humano ou não humano) } \\
\hline $\begin{array}{c}\text { Relação sujeito } \leftrightarrow \text { sujeito } \\
\text { (simetria, reciprocidade, troca, reversibilidade). } \\
\text { Ao abarcar sujeitos humanos e não humanos, } \\
\text { estabelece o domínio universal da Cultura. }\end{array}$ & $\begin{array}{c}\text { Relação sujeito } \rightarrow \text { objeto } \\
\text { (assimetria, representação, poder, dominação, posse). } \\
\text { Cria a Natureza-objeto, em oposição ao } \\
\text { Homem-sujeito, detentor de Cultura. }\end{array}$ \\
\hline $\begin{array}{c}\text { Cosmocentrismo } \\
\text { e pluralismo cosmológico } \\
\text { (admite uma pluralidade de sujeitos não humanos: } \\
\text { plantas, animais, artefatos, espíritos etc.). }\end{array}$ & $\begin{array}{c}\text { Antropocentrismo } \\
\text { (egocentrismo, etnocentrismo, } \\
\text { eurocentrismo, falocentrismo etc.). }\end{array}$ \\
\hline $\begin{array}{c}\text { 'Produção' de sujeitos e subjetividades - } \\
\text { de sociabilidades. }\end{array}$ & $\begin{array}{l}\text { Produção de objetos, mercadorias. } \\
\text { O triunfo das coisas. }\end{array}$ \\
\hline $\begin{array}{c}\text { Relação com o invisível (interior, intensivo, subjetivo) } \\
\text { que também é o anímico, o espiritual. }\end{array}$ & Relação com o visível (exterior, extensivo, objetivo). \\
\hline $\begin{array}{l}\text { O outro é um 'eu' } \\
\text { (um sujeito, um rosto, um olhar, uma fala, } \\
\text { um pensamento, um modo de ser, um ponto de vista). }\end{array}$ & $\begin{array}{l}\text { Negação do outro } \\
\text { (escravismo, racismo, xenofobia, homofobia, } \\
\text { tortura, feminicídio, etnocídio, genocídio). }\end{array}$ \\
\hline Ser olhado/afetado pelo outro. & Olhar (ou deixar de olhar) o outro. \\
\hline Relação social, dialógica, ética e poética. & Negação da ética. \\
\hline Anima (princípio feminino) - Eros. & Animus (princípio masculino) - Logos. \\
\hline Alteridade (o novo, o diferente). & Identidade (o mesmo). \\
\hline Pensamento poético/metafórico. & Pensamento lógico. \\
\hline $\begin{array}{l}\text { A é B (torna-se outro). } \\
\text { 'Eu é um outro'. }\end{array}$ & A é $A, B$ é $B$. \\
\hline $\begin{array}{l}\text { O homem pertence à terra. } \\
\text { A terra é 'mãe' (sujeito feminino). }\end{array}$ & A terra pertence ao homem. \\
\hline $\begin{array}{l}\text { Cultura da floresta - } \\
\text { mata cultural, floresta-pomar, floresta-jardim } \\
\text { (a floresta que é jardim, sem deixar de ser floresta). }\end{array}$ & $\begin{array}{l}\text { Negação da floresta - } \\
\text { sua conversão em madeira, celulose, carvão, pasto, } \\
\text { monocultura, mineração, rodovia, ferrovia, cidade. }\end{array}$ \\
\hline Aumento da biodiversidade & Perda de biodiversidade \\
\hline $\begin{array}{c}\text { Amazônia antropogênica } \\
\text { Natureza } \leftrightarrow \text { Cultura }\end{array}$ & $\begin{array}{l}\text { Amazônia antropizada* } \\
\text { Natureza } \rightarrow \text { Cultura }\end{array}$ \\
\hline A floresta como 'sujeito'. & $\begin{array}{l}\text { A floresta como natureza, meio ambiente ou paisagem } \\
\text { ('objeto' do nosso olhar estético-cultural, das nossas } \\
\text { representações artísticas, do nosso conhecimento } \\
\text { científico, das nossas leis de proteção). }\end{array}$ \\
\hline
\end{tabular}

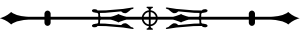


O Ocidente 'criança e poeta' vai além ${ }^{13}$. $\bigcirc$ homem ou a mulher ocidental, enquanto 'poeta' (guiado/guiada por um pensamento ético e poético), se reconhece nos povos indígenas e na sua experiência de mundo. Se há um terreno comum entre o Ocidente e as culturas ameríndias da floresta tropical, o terreno de um mútuo reconhecimento e uma brecha no seu antagonismo, é este. Crianças e poetas de todo o mundo se reconhecem nos povos indígenas, habitantes da Terra-Floresta, pois estes são como as crianças e os poetas ${ }^{14}$, por 'verem o invisível' (invisível ao adulto prosaico) e atribuírem alma a todas as coisas. Há um animismo poético irmão do animismo ameríndio.

O filósofo Gaston Bachelard, ao explorar os domínios da "imaginação material e dinâmica" na poesia, viu na riqueza e vivacidade das imagens poéticas

\begin{abstract}
... um animismo que verdadeiramente anima, que encontra no mundo inanimado todas as nuanças de uma vida sensível e voluntária, que lê a natureza como uma móvel fisionomia humana. . . . Os poetas, em seus devaneios cósmicos, falam do mundo com a linguagem do mundo. . . . No devaneio cósmico, nada é inerte, nem o mundo, nem o poeta em devaneio; tudo é animado por uma vida secreta, portanto tudo fala com sinceridade. $O$ poeta escuta e repete. A voz do poeta é uma voz do mundo. (Bachelard, 1942, p. 207, 1960, p. 162).
\end{abstract}

O mundo, sendo sujeito, 'fala' ao poeta e através do poeta! A imaginação poética, para Bachelard (1942, p. 25), é "a faculdade de formar imagens que ultrapassam a realidade" (ou seja, o visível, a exterioridade) e é o que nos proporciona "a faculdade de nos maravilhar". $\bigcirc$ psicoterapeuta junguiano Roberto Gambini, por sua vez, confere à psique indígena brasileira "um peculiar senso de maravilhamento diante dos mistérios da vida e da natureza" (Gambini, 2000, p. 165), dignifica o animismo ameríndio por "atribuir sacralidade às coisas" e descreve "o grande drama de nossa origem, na data de 1500"15:

Tínhamos então, e ainda nos sobrou mais do que conseguimos acolher, uma verdadeira enciclopédia de mitos, imagens e sentidos, e isso se chama alma. Alma antiga ligada à Terra, arraigada no solo. A alma estava na luz do Sol, no escuro da noite, nos astros, nas árvores, nos rios, na semente que brotava, nos animais. Os antropólogos do século XIX pejorativamente chamaram essas concepções de animismo, um modo primitivo de funcionamento psíquico por atribuir sacralidade às coisas. $\bigcirc$ fato é que o território brasileiro como um todo estava impregnado de sacralidade, porque o homem anterior ao "descobrimento" comungava, ao viver, com a natureza e com tudo que a povoava. Esse tesouro humano, criação lentamente configurada no decorrer de milênios, foi destruído de um só golpe por obra de um olhar estrangeiro que o distorceu e negou. (Gambini, 2000, p. 161).

De maneira inigualável, o escritor e poeta Euclides da Cunha percebeu e expressou a Hileia - e toda a physis amazônica - como sujeito. Pois é na Amazônia que

as coisas duramente objetivas se revestem de uma anômala personalidade. Matas a caminharem, vagarosamente, viajando nas planuras, ou estacando, cautas, à borda das barreiras a pique, a refletirem, na desordem dos ramalhos estorcidos, a estupenda conflagração imóvel de uma luta perpétua e formidável; lagos que nascem, crescem,

13 Podendo o cientista e o poeta coexistirem num mesmo indivíduo, claro!

14 O que o indígena, a criança e o poeta têm em comum é a percepção 'anímica' do mundo, ou seja, a capacidade superior de perceber o mundo, não como objeto, mas como sujeito. Em "Totem e Tabu", Freud, apesar de tratar os indígenas como "primitivos" e o animismo como estágio da humanidade a ser superado, expressa muito bem este parentesco entre a criança e o indígena: "Há muita semelhança entre a relação das crianças com os animais e a dos primitivos. A criança não mostra ainda nenhum traço da arrogância que leva o homem adulto civilizado a desenhar uma fronteira nítida entre a sua natureza e a dos outros animais. Sem hesitação, a criança vê o animal como seu igual" (Freud, 2013, p. 131).

${ }^{15}$ Cena originária que Gambini define também como "drama arquetípico", "gigantesco confronto entre o consciente e o inconsciente, entre racionalidade e não racionalidade", entre Logos e Eros, entre o animus masculino e a anima feminina. A América representaria os "domínios de Eros" e "o mundo do inconsciente, um mundo regido pelo pensamento não linear, não lógico, mas dialógico, associado aos sentidos, à observação do natural e ao respeito pelo sobrenatural, mas nem por isso menos pensamento. . . . A anima é o arquétipo da vida e da alegria de viver. É a anima que permite a um homem abrir-se para o inconsciente, relacionar-se com a natureza e nela encontrar beleza e sentido. . . . América é mulher, terra e anima". (Gambini, 2000, pp. 134, 141, 143, 164-166). A propósito, Poesia também é anima - "o puro devaneio poético é uma manifestação da anima", diz Bachelard (1960, p. 55).

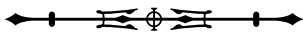


se articulam, se avolumam no expandir-se de uma existência tumultuária . . . ; rios pervagando nas solidões encharcadas, à maneira de caminhantes precavidos, temendo a inconsistência do terreno, seguindo "com a disposição cautelosa das antenas dos furos". . . . É a terra moça, a terra infante, a terra em ser, a terra que ainda está crescendo . . . Agita-se, vibra, arfa, tumultua, desvaira. A sua fisionomia altera-se diante do espectador imóvel. Naquelas paisagens volúveis imaginam-se caprichos de misteriosas vontades. (Cunha, 2008, pp. 24-26).

Precisamente, é aos artistas enquanto poetas que o filósofo Henri Bergson concede o privilégio de uma percepção 'outra', poética, libertadora. Contra a nossa percepção ordinária - estreita, utilitária, prosaica - das coisas e dos seres enquanto 'objetos', irrompe e resplandece, segundo ele, a percepção "dilatada e ilimitada" própria aos artistas, cuja função é "ver e fazer-nos ver o que não percebemos naturalmente", isto é, aspectos da realidade que permaneciam virtuais e invisíveis até serem "revelados", a exemplo da imagem fotográfica que ainda não foi imersa no banho de revelação. "O poeta é este revelador"16, afirma Bergson (2011, pp. 10-12), por ele ser, literalmente, um "distraído" - "ao invés de perceber para agir, ele percebe para perceber" (Bergson, 2011, nota 33, p. 45).

Ademais, ao relacionar os objetos da nossa percepção ordinária com a imobilidade e a imutabilidade, Bergson (2011) nos ajuda a entender melhor a natureza do sujeito, qual seja: sujeito é o completamente 'outro', isto é, o novo, o diferente: vivo, ativo, movente, mutável (de natureza temporal), autônomo, criador, indeterminado, imprevisível, surpreendente - em oposição ao objeto, isto é, o 'mesmo': fixo, estático, estável (de natureza espacial e atemporal), idêntico, invariável, mensurável, visível e previsível, representado, subjugado, passivo, morto.

Neste sentido, sujeito é o vir-a-ser, o devir, o tornarse-outro, a exemplo do sujeito ameríndio por excelência: a Floresta Amazônica.

\section{EPÍLOGO. LIÇÕES DE SABEDORIA AMAZÔNICA: POR UMA RELAÇÃO ÉTICA E POÉTICA COM O MUNDO}

É possível combinar/articular/correlacionar cosmologias indígenas e Ecologia Histórica, na Amazônia? Articular, por exemplo, o animismo ameríndio (tudo é sujeito) com a existência de matas culturais? Sim, e o pesquisador e teórico Marcos Magalhães nos ajuda nisso. A articulação se dá, precisamente, dentro do novo conceito de "antropogênese amazônica", ou de "Amazônia antropogênica", por ele proposto (Magalhães, 2016, 2018). Como vimos, a floresta amazônica só se tornou "antropogênica" (sendo 'jardim', sem deixar de ser "floresta'17) em razão de ela ter sido Sujeito para o Homem ao longo dos milênios - por ter havido entre o Homem e a Floresta uma relação face a face, ética e poética, de Sujeito para Sujeito.

O saber específico proveniente desta relação: a ecocosmologia (ou cosmoecologia) dos Povos da Floresta, com suas infinitas versões e variações, constitui uma sofisticada criação cultural (material e simbólica) e compõe um 'sistema' tão grandioso, complexo e diverso quanto a própria floresta amazônica. Para nós, este saber tem valor de sabedoria. A falência do homem ocidental, do modo ocidental de relacionar-se com o outro,

16 poeta como vidente e revelador do invisível. Tanto na experiência poética quanto na experiência ameríndia, ver no não humano um sujeito ou uma pessoa equivale a ultrapassar a realidade visível, exterior, e 'ver o invisível': a interioridade subjetiva ou anímica do mundo, que transparece poeticamente como rosto, fisionomia. "A adesão ao invisível, eis a poesia primeira", dizia Bachelard (1942, p. 25), e a adesão ao invisível mundo das subjetividades não humanas, eis o que aparenta a experiência ameríndia com a experiência poética.

17 Fórmula que expressa uma verdade ecológica e ao mesmo tempo poética, uma metáfora. A metáfora, figura de linguagem poética, diz: "A é B" - havendo, por trás deste "é" metafórico, um "não é" lógico (cf. Ricœur, 1975, pp. 37, 312-313). Na Amazônia antropogênica, a floresta é e não é um jardim, ou é floresta e jardim ao mesmo tempo, ou é jardim, sem deixar de ser floresta. A metáfora provoca a surpresa ao criar uma "impertinência semântica", aproximando e tornando equivalentes coisas logicamente distantes (o rio e a rua, por exemplo, na canção paraense "Este rio é minha rua . . ."), e ao mesmo tempo preserva a distância lógica entre elas (pois sabemos que o rio não é a rua - ou então é rua, sem deixar de ser rio); a verdade que ela expressa não é uma verdade lógica, mas uma "verdade metafórica" (algo é A e B ao mesmo tempo), ou verdade poética - com a qual a verdade científica, algumas vezes, é capaz de concordar.

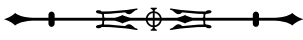


humano ou não humano (uma relação entre sujeito e objeto, violenta, autoritária, arrogante, colonialista, dominadora), exige uma alternativa radical. Essa alternativa, o Brasil a possui em grau de excelência: é um dos seus maiores tesouros. Tesouro nativo, vilipendiado desde o princípio, quando o Ocidente para cá se estendeu com violência surda e cega, com base na total negação do outro, contra a alma e o corpo indígenas. Tesouro da sabedoria ameríndia: o não humano como sujeito - uma relação ética e poética com o outro. Hoje, o Ocidente falido, espalhando a catástrofe planetária, 'reinventa' as sabedorias ancestrais por ele negadas, criando 'novas' práticas e 'novos' conceitos: sustentabilidade, agroecologia, agrofloresta, permacultura, agricultura sintrópica, ecologia profunda, teoria de Gaia etc. Não há como negar a "contemporaneidade absoluta" (Kopenawa \& Albert, 2015, p. 34) dos povos originários - para usar a fórmula certeira de Eduardo Viveiros de Castro. De fato, os povos originários, os ameríndios, com sua sabedoria milenar, amazônica, florestal, sua cultura da floresta, são cada vez mais atuais e contemporâneos, cada vez mais na ordem do dia - do planeta e da humanidade.

\section{POST-SCRIPTUM}

No Brasil, país situado, como se sabe, no ExtremoOcidente, as culturas indígenas, que resistiram e sobreviveram ao genocídio, são culturas de resistência (e de 're-existência') - como as culturas de matriz africana, suas irmãs gêmeas. Resistindo e se mantendo vivas em território próprio, elas mantêm viva a sua alteridade radical com relação ao Ocidente (ao Estado, ao Capital): algo inadmissível para o pensamento autoritário. Por isso, continua em vigor a lógica do genocídio, cujo meio e fim é a tomada das terras indígenas ${ }^{18}$.

\section{REFERÊNCIAS}

Albert, B., \& Kopenawa, D. (2003). Yanomami, l'esprit de la forêt. Paris: Fondation Cartier pour l'art contemporain.

Bachelard, G. (1942). L'eau et les rêves: essai sur l'imagination de la matière. Paris: Librairie José Corti.

Bachelard, G. (1960). La poétique de la rêverie. Paris: PUF.

Balée, W. (1989). Cultura na vegetação da Amazônia brasileira. In W. A. Neves (Org.), Biologia e ecologia humana na Amazônia: avaliação e perspectivas (Coleção Eduardo Galvão, pp. 95-109). Belém: MPEG.

Bergson, H. (2011). La perception du changement (Coleção Quadrige Grands Textes). Paris: PUF.

Clastres, P. (2003). A sociedade contra o Estado: pesquisa de antropologia política. (T. Santiago, Trad.). São Paulo: Cosac Naify.

Cunha, E. (2008). Preâmbulo. In A. Rangel. Inferno verde (6 ed., pp. 21-31). Manaus: Editora Valer.

Declaração de Belém+30. (2018, agosto). In XVI Congresso da Sociedade Internacional de Etnobiologia, XII Simpósio Brasileiro de Etnobiologia e Etnoecologia, I Feira Mundial da Sociobiodiversidade, IX Feira Estadual de Ciência, Tecnologia e Inovação. Belém: UFPA, MPEG.

Declaração de Belém. (1988, julho). In D. A. Posey \& W. L. Overal (Orgs.), Ethnobiology: implications and applications. Proceedings of the First International Congress of Ethnobiology (Belém, 1988). Belém: MPEG.

Descola, P. (1986). La Nature domestique: symbolisme et praxis dans l'écologie des Achuar. Paris: Ed. de la Maison des Sciences de l'Homme.

Descola, P. (2005). Par-delà nature et culture. Paris: Gallimard.

Freud, S. (2013). Totem e Tabu: algumas concordâncias entre a vida psíquica dos homens primitivos e a dos neuróticos (P. C. Souza, Trad.). São Paulo: Companhia das Letras.

Gambini, R. (2000). Espelho índio: a formação da alma brasileira (2 ed.). São Paulo: Axis Mundi.

Heidegger, M. (1958). Science et méditation (A. Préau, Trad.). In Essais et conférences (Coleção Tel, 52, pp. 49-79). Paris: Gallimard.

${ }^{18}$ Em "Como conversar com um fascista", a filósofa Marcia Tiburi faz a defesa e ilustração da alteridade no Brasil de hoje. Os capítulos finais são dedicados aos povos nativos, à alteridade indígena e ao genocídio em curso. A questão fundamental, que atravessa o livro, é o tipo de relações que estabelecemos com o outro: relações sujeito-sujeito (éticas, políticas, democráticas, dialógicas, amorosas) ou relações sujeito-objeto (antiéticas, antipolíticas, autoritárias, violentas, fascistas). O projeto e a quintessência do pensamento autoritário são assim definidos: "A morte do outro - o outro não existe e se existe deve ser eliminado" (Tiburi, 2016, pp. 40, 159). 
Heidegger, M. (1962). L'époque des 'conceptions du monde'. L'origine de l'œuvre d'art (W. Brokmeier, Trad.). In Chemins qui ne mènent nulle part (Coleção Tel, 100, p. 13, p. 99). Paris: Gallimard.

Heidegger, M. (1968). Identité et différence. Ce qu'est et comment se détermine la physis (A. Préau \& F. Fédier, Trads.). In Questions $I$ et II (Coleção Tel, 156, p. 253, p. 471). Paris: Gallimard.

Hemingway, E. (1962). O velho e o mar (F. C. Ferro, Trad., 8 ed.). Rio de Janeiro: Civilização Brasileira.

Kopenawa, D., \& Albert, B. (2015). A queda do céu: palavras de um xamã yanomami (B. Perrone-Moisés, Trad., \& E. Viveiros de Castro, Pref.). São Paulo: Companhia das Letras.

Leopoldo e Silva, F. (2017). Da ética à antiética: notas para compreender a supremacia da violência. In A. Novaes (Org.). Mutações: entre dois mundos (pp. 93-111). São Paulo: Edições SESC.

Magalhães, M. P. (Org.). (2016). Amazônia antropogênica. Belém: MPEG.

Magalhães, M. P. (Org.). (2018). A humanidade e a Amazônia: 11 mil anos de evolução histórica em Carajás. Belém: MPEG.

Mancuso, S. \& Viola, A. (2018). L'intelligence des plantes (R. Temperini, Trad.). Paris: Albin Michel.

Pardini, P. (2012). Natureza e cultura na paisagem amazônica: uma experiência fotográfica com ressonâncias na cosmologia ameríndia e na ecologia histórica. Boletim do Museu Paraense Emílio Goeldi. Ciências Humanas, 7(2), 589-603. doi: 10.1590/ S1981-81222012000200017

Pinto, L. F. (2006a, agosto $1^{\text {a }}$ quinz.). Como ser amazônida: a cultura da floresta. Jornal Pessoal, (373), pp. 6-8.
Pinto, L. F. (2006b, junho $1^{\mathrm{a}}$ quinz.). Eu sou amazônida. E você? [Reeditado in: Jornal Pessoal, (654), pp. 6-7, $2^{\text {a }}$ quinz. maio 2018]. Jornal Pessoal, (369), pp. 6-7.

Pozzobon, J. (2002). Iniciação. In J. Pozzobon. Vocês, brancos, não têm alma: histórias de fronteiras (p. 25). Belém: EDUFPA.

Ricour, P. (1975). La métaphore vive. (Points Essais, n. 347). Paris: Éditions du Seuil.

Rimbaud, A. (1984). Lettres dites du voyant. In Poésies complètes. (Le Livre de Poche, n. 5924, pp. 199-205). Paris: Librairie Générale Française.

Tible, J. (2013). Marx selvagem. São Paulo: Annablume.

Tiburi, M. (2016). Como conversar com um fascista: reflexões sobre o cotidiano autoritário brasileiro. (5 ed.) Rio de Janeiro: Record.

Todorov, T. (2011). A Conquista da América: a questão do outro (B. Perrone-Moisés, Trad., 4. ed.). São Paulo: Martins Fontes.

Viveiros de Castro, E. (2005). O perspectivismo ameríndio ou a natureza em pessoa. Ciência \& Ambiente, (31), pp. 123-132.

Viveiros de Castro, E. (2006). A floresta de cristal: notas sobre a ontologia dos espíritos amazônicos. Cadernos de campo, (14/15), pp. 319-338. Recuperado de http://www.journals.usp.br/ cadernosdecampo/article/download/50120/55708

Zent, S., \& Zent, E. (2012). Jodi horticultural belief, knowledge and practice: incipient or integral cultivation? Boletim do Museu Paraense Emílio Goeldi. Ciências Humanas, 7(2), 293-338. doi: 10.1590/S1981-81222012000200003 
